\title{
Using Mobile Applications: A Model of Technology Adoption in the Grocery Setting
}

\author{
Simone Aiolfi ${ }^{1} \&$ Silvia Bellini ${ }^{1}$ \\ ${ }^{1}$ Department of Economics and Management, University of Parma, Italy \\ Correspondence: Simone Aiolfi, Department of Economics and Management, University of Parma, Via Kennedy \\ 6, 43125 Parma, Italy. E-mail: simone.aiolfi@unipr.it
}

Received: July 15, 2019

Accepted: September 29, 2019

Online Published: November 8, 2019

doi:10.5539/ijbm.v14n12p42

URL: https://doi.org/10.5539/ijbm.v14n12p42

\begin{abstract}
One of the most discussed topics in the academic literature is the adoption of new technologies by consumers. However, researchers conducted few studies on the adoption of mobile apps for grocery shopping. Particularly, the few researches carried out focused on the adoption of mobile commerce by consumers, while no study was concerned with the use of mobile applications out-of-store, as means for shopping preparation or in-store, as tools for self-regulation. Since individuals are becoming increasingly reliant on mobile technologies, understanding the role of mobile devices in influencing the attitude of consumers towards the app's adoption in the grocery retail setting is extremely important for retailers and manufacturers who should develop mobile apps to exploit consumers' mobile dependence in order to influence consumer and buying behavior during the path-to-purchase. The study we proposed led to the development of a new version of the technology adoption model of a smart mobile application for grocery shopping, in the Italian retail context, which could help researchers and managers better understand the shoppers' behaviour in the new retail landscape. Our model includes variables related to the use of the mobile both out-of-store, as a means of shopping preparation, and in-store, as a tool for self-regulation.
\end{abstract}

Keywords: mobile application, technology adoption, consumer behavior, shopper marketing, innovation, SEM

\section{Introduction}

One of the most discussed topics in the academic literature is the adoption of new technologies by consumers. Recently, research on the adoption of mobile applications by individuals for activities related to mobile commerce has appeared in the academy. However, few studies have been conducted on the adoption of mobile apps for grocery shopping (Shukla \& Sharma, 2018). In particular, the few researches carried out focused on the adoption of mobile commerce by consumers, while no study was concerned with the use of mobile applications as tools for shopping preparation out-of- store or as tools for self-regulation inside the store.

Indeed, over the last few years, the widespread mobile connectivity has significantly influenced consumer decision-making process. In the retail setting, mobile devices are used out-of-store, to collect information before entering the store, as well as in-store, as a guide for shopping, especially to check the digital shopping list, search for information on promotions or use the retailer's app.

Moreover, the widespread mobile connectivity and the increasing penetration of mobile devices have strengthened these trends making consumers much more planned and prepared than before.

Since the individuals are becoming increasingly dependent on mobile technologies during their daily lives, understanding the role of mobile devices in influencing the attitude of consumers towards the adoption of a mobile app in a retail grocery context is extremely important for retailers and manufacturers. If a more planned and prepared consumer is more likely to adopt a mobile application during the buying process for activities related to grocery shopping, retailers should develop mobile applications to exploit consumers' dependence on mobile technology with the aim to influence consumer and buying behavior during the entire path-to-purchase.

The growing penetration of mobile devices has provided firms with an unprecedented opportunity to engage consumers but to know how to take advantages from this tool it is important to investigate the impact of mobile devices on consumer outcomes. Therefore, it becomes crucial to understand how the mobile influences the decision-making process as well as the buying behavior of shoppers. 
For all these reasons, we decided to propose a study that led to the development of a new model of smart mobile app adoption in the Italian grocery setting, which could help researchers and managers better understand the behavior of shoppers in the new retail landscape. The aim of the research is therefore to create a new version of the technology adoption model of a mobile application for grocery shopping that includes variables related to the phenomenon of the use of the mobile device both out-of-store, as a means of shopping preparation, and in-store, as a tool for self-regulation.

\section{Theoretical Framework and Research Objectives}

Academic literature has always focused attention on the use of technology looking for the antecedents associated with the intention to use a specific technology.

In literature, there are three main theories behind the adoption of a new technology: the theory of reasoned action (TRA), the theory of planned behavior (TPB) and the model of acceptance of the technology (Technology Acceptance Model, TAM).

The theory of reasoned action (Fishbein \& Ajzen, 1975) provides a basic framework that helps researchers understand how individuals' behaviors come to fruition. The general model does not refer to specific behaviors and is therefore applicable to different studies and to the particular type of behavior that one intends to analyze. The basis of the theory of reasoned action is the identification of three predictive factors: the Behavioral Intention, understood as direct action towards a specific conduct; the personal Attitude towards the behavior, that is the attitude that an individual has in adopting or not adopting a specific behavior following a positive or negative judgment attributed to the particular behavior; the Subjective Norm, that is the influence that the opinions of others exert on the choices of the individual (Fishbein \& Ajzen, 1975; Taylor \& Todd, 1995).

Subsequently, Ajzen (1991) modified the model of reasoned action, formulating the planned behavior theory. Ajzen (1991) introduced a new variable, perceived behavioral control, as the perception that a subject has to be able to implement the desired behavior. This indirect control, distinct from real control, affects both the intention to implement a given behavior and the behavior itself (Ajzen, 1991; Taylor \& Todd, 1995).

Finally, the technology acceptance model was designed based on reasoned action theory to predict the likelihood of a new technology being adopted by a group of individuals or companies (Davis, 1989; Davis, Bagozzi \& Warshaw, 1989; Shukla \& Sharma, 2018). The purpose of the TAM was to provide a useful model for researchers to analyze the cause of rejection or acceptance of a technology. The TAM model suggests how the Perceived Usefulness (PU) and the Perceived Ease of Use (PEOU) are the two determining factors for the adoption of any technology understood. Literature defines the Perceived Usefulness as the belief that a technology can improve a certain activity and the Perceived Ease of Use as the perception of ease or difficulty in using a given technology. These two antecedents affect the Attitude Towards Technology Use (AT) which, if positive, will in turn influence the "behavioral intention" or the Intention To Use Technology (BI) (Davis, 1989; Davis, Bagozzi \& Warshaw, 1989). Furthermore, external variables, such as information, supporting the technology, available to the consumer, may influence both perceived usefulness and perceived ease of use (Davis, 1989; Davis, Bagozzi \& Warshaw, 1989). Unlike the TRA, the TAM does not consider variables that specifically measure social influence on individual behavior as the subjective norms of Fishbein \& Ajzen (1975).

The TAM model was used in the literature to initially explain the adoption of computers (Davis 1989; Davis, Bagozzi \& Warshaw, 1989). Subsequently, with the evolution of the Internet and mobile technologies, numerous studies have confirmed the validity of the TAM model in the analysis of the adoption of several technologies, ranging from software packages to online and mobile services, in different sectors, from fashion to finance and medicine (Venkatesh \& Davis, 1996; Hu et al., 1999; Karahanna \& Straub, 1999; Roberts \& Henderson, 2000; Hackbarth, Grover \& Mun, 2003; McKechnie, Winklhofer \& Ennew, 2006; Ko, Kim \& Lee, 2009; Park, 2009; Moon \& Domina, 2015; Venkatesh, Thong \& Xu, 2012). Over the years, some re-elaborations of the original formulation of the TAM model have been proposed, such as the TAM2 (Technology Acceptance Model second version) by Venkatesh \& Davis (2000), the Unified Theory of Acceptance and the Use of Technology (UTAUT), an extension of the original TAM proposed by Venkatesh et al. (2003) and finally the TAM3 (Technology Acceptance Model third version) by Venkatesh and Bala (2008).

Ultimately, the TAM acceptance model is a solid theoretical and methodological starting point for predicting the behavior of potential and real users and their attitude towards a technology. Therefore, we decided to build the study on the adoption of mobile app for grocery shopping based on the TAM model by Davis (1989) \& Davis, Bagozzi \& Warshaw (1989). Within the scope of this research, Shukla \& Sharma (2018) have already used the TAM model for the construction of the Framework of Technology Acceptance towards Grocery Shopping Using Mobile. The authors have built the model of acceptance of mobile apps for shopping in the grocery world 
considering all the variables included in the original TAM model and for the first time contextualized in the grocery context (Shukla \& Sharma, 2018). The authors' goal was to understand the factors that determine the acceptance of a mobile app to buy grocery goods from Indian consumers.

In the same way, we decided to replicate the study in Italy where the dependency on mobile devices has assumed such importance that Italians, constantly connected during their daily lives, have been declared to be the most "mobile addicted" population in Europe (Deloitte, 2017).

The increasing use of mobile devices is not only changing the way we interact and communicate with individuals, but is also influencing, in a disruptive way, our decision-making process. Specifically, mobile devices could be used out-of-store, to collect information during the preparatory activities, as well as in-store, as a guide for shopping. Today shoppers dedicate time and effort to prepare the shopping expedition both before entering the store and inside the store in order to be less conditioned by the in-store marketing stimulus promoted by retailers (Heckhausen \& Gollwitzer, 1987; Iyer \& Ahlawat, 1987; Thomas \& Garland, 2004; Bellini, Cardinali \& Grandi, 2016 and 2017; Bellini \& Aiolfi, 2017). Shoppers, in fact, recognize the ability of retailers to create immediate desires through the management of the in-store marketing levers and rationally try to limit their effect through the activation of "self-control strategies". In this context, the shopping list has always been the most widespread tool, as it is used by consumers as an external memory aid (Block \& Morwitz, 1999).

The importance of the shopping list has grown exponentially in recent years thanks to the diffusion of digital and mobile technologies that allow consumers to prepare the shopping activity with different tools and apps (Bellini, Cardinali \& Grandi, 2016). The mobile apps development has allowed consumers to search for information anywhere and anytime, both outside and inside the store, together with the possibility to draw up the digital shopping list and carry out other pre-shopping preparation activities (Silveira \& Marreiros, 2014). Recent research has shown that the degree of shopping preparation influences the behavior of shoppers inside the store in terms of planned/unplanned purchases: the greater the tendency to plan purchases, the lower the tendency to make impulse purchases (Bellini, Cardinali \& Grandi, 2016).

In this perspective, a grocery mobile application could represent a positive asset for consumers as it contributes to improve the quality of their decisions, reducing cognitive efforts during the shopping trip.

\section{Conceptual Framework and Hypotheses}

The new model will include all the original variables of the TAM model. However, the aim of our research is, therefore, to create a new version of the technology adoption model of a mobile application for activities related to grocery shopping by Italian consumers, which includes among the antecedents of the adoption of the smart technology the PrePurchase Planning. In line with previous research, we defined PrePurchase Planning as the consumer's propensity to plan the shopping expedition implementing preparatory behaviors and develop precise and clear purchase intentions before entering the store (Gauri, Sudhir \& Talukdar, 2008; Bellini, Cardinali \& Grandi, 2017). This variable is strictly related to the phenomenon of the use of the mobile device out-of-store, as a tool for shopping preparation, and in-store, as a tool for self-regulation. For these reasons, our revised model of the adoption of the mobile application in the grocery setting is not about the use of the mobile application as a tool to make grocery purchases but as a tool to facilitate shoppers during their shopping expedition and make shopping experience in-store more personalized.

\begin{tabular}{|l|l|l|l|}
\hline \multicolumn{1}{|c|}{ CONSTRUCT } & \multicolumn{1}{|c|}{ DEFINITION } & TEMPLATE & \multicolumn{1}{c|}{ REFERENCES } \\
\hline Perceived Usefulness (PU) & $\begin{array}{l}\text { Perception by the consumer } \\
\text { of utility deriving from the } \\
\text { use of the mobile application } \\
\text { for activities related to } \\
\text { grocery shopping }\end{array}$ & TAM & Davis (1989) \\
\hline $\begin{array}{l}\text { Perceived Ease } \\
\text { Of Use (PEOU) }\end{array}$ & $\begin{array}{l}\text { Perception of ease or reduced } \\
\text { difficulty in using the mobile } \\
\text { application for activities } \\
\text { related to grocery shopping }\end{array}$ & TAM & Davis (1989) \\
\hline $\begin{array}{l}\text { Attitude Toward The } \\
\text { Grocery App (AT) }\end{array}$ & $\begin{array}{l}\text { Positive or negative attitude } \\
\text { of the consumer towards } \\
\text { using a mobile application for } \\
\text { activities related to grocery } \\
\text { shopping }\end{array}$ & TRA & Fishbein and Ajzen (1975) \\
\hline $\begin{array}{l}\text { Intention To Use The } \\
\text { Grocery App (BI) }\end{array}$ & $\begin{array}{l}\text { Probability of using } \\
\text { the mobile application for } \\
\text { activities related to grocery } \\
\text { shopping }\end{array}$ & TRA & Fishbein and Ajzen (1975) \\
\hline Prepurchase Planning & $\begin{array}{l}\text { Propensity of the consumer to } \\
\text { carry out preparatory } \\
\text { activities for grocery } \\
\text { shopping in order to plan the } \\
\text { shopping expedition }\end{array}$ & $\begin{array}{l}\text { Mobile Impulse } \\
\text { Buying }\end{array}$ & $\begin{array}{l}\text { Gauri, Sudhir and Talukdar } \\
\text { (2008); Bellini, Cardinali and } \\
\text { Grandi (2017) }\end{array}$ \\
\hline
\end{tabular}

Figure 1. Constructs used in research 
The conceptual model proposed in this study is based on the original TAM model re-elaborated according to the definitions of the variables proposed in Figure 1. Therefore, our revisited model is built on the following hypotheses:

\section{H1: The higher the level of Perceived Ease of Use, the higher the level of Perceived Usefulness}

H2: The level of Perceived Ease of Use positively influences the Attitude towards the Grocery App

H3: There is a positive relationship between the Perceived Usefulness of the app for grocery shopping and the Attitude Towards the Grocery App

H4: The Attitude towards the Grocery App has a positive influence on the Intention to use the Grocery App

H5: Perceived Usefulness positively affects the Intention to use the Grocery App

Today shoppers dedicate time and effort to prepare the shopping expedition both before entering the store and during the visit to the store in order to be less conditioned by the in-store marketing stimulus promoted by retailers (Heckhausen \& Gollwitzer, 1987; Iyer \& Ahlawat, 1987; Thomas \& Garland, 2004; Bellini, Cardinali \& Grandi, 2016 and 2017; Bellini \& Aiolfi, 2017). Since shoppers tend to be more and more prepared today, as confirmed by Bellini, Cardinali \& Grandi (2016), it is likely that the tendency to planning pushes them to use a mobile application for activities related to shopping generating a positive attitude towards the app that could result in an effective use for activities related to grocery shopping. Therefore, from these considerations the following hypotheses arise in addition to the five hypotheses identified in the re-elaboration of the TAM model:

H6: The degree of PrePurchase Planning positively influences the Attitude Towards the Grocery App

H7: The degree of PrePurchase Planning positively influences the Intention to Use the Grocery App

Figure 2 illustrates all seven hypotheses tested in the model.

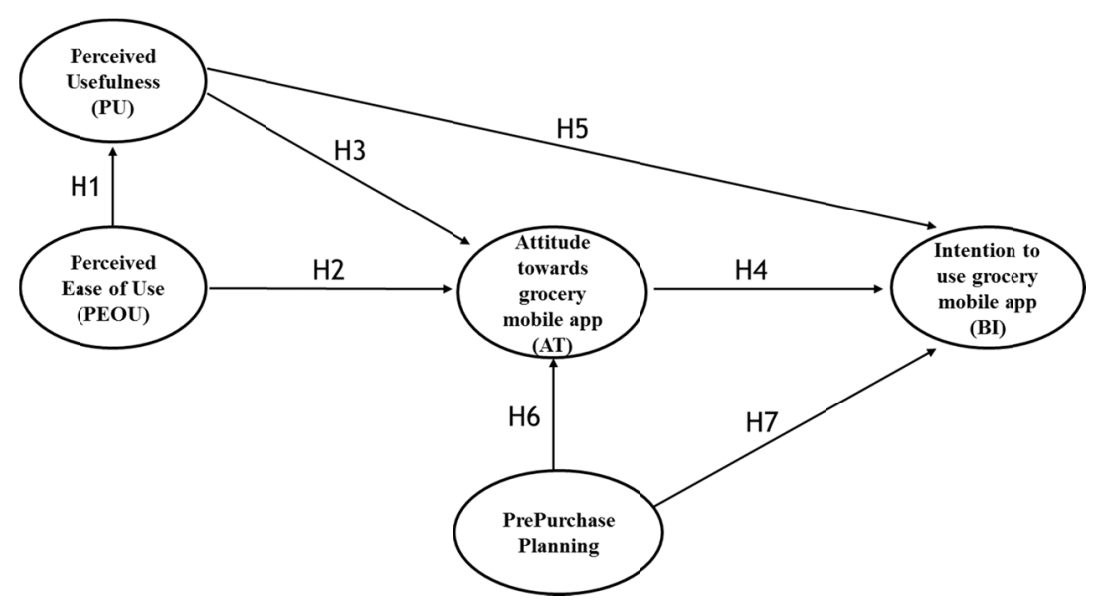

Figure 2. Conceptual framework

\section{Methodology}

\subsection{Sample}

To test all the hypotheses, we used a quantitative survey method based on data collection using a questionnaire administered online with the belief that consumers who surf the Web represent the most suitable target for the research objectives. We requested them to answer to a structured questionnaire. A total of 273 subjects were interviewed and Table 1 illustrates the demographic characteristics of the sample. 
Table 1. Demographic profile of the sample

\begin{tabular}{lll}
\hline Features & & Percentage \\
\hline Gender & Females & 61.9 \\
Age group & Males & 38.1 \\
& Under 20 & 3.7 \\
& $20-24$ & 31.1 \\
& $25-29$ & 28.6 \\
& $30-34$ & 9.5 \\
& $35-44$ & 8.8 \\
& $45-54$ & 7.7 \\
& $55-65$ & 8.8 \\
& Over 65 years & 1.8 \\
\hline
\end{tabular}

\subsection{Procedure}

We first asked online respondents if they usually used their mobile devices during their grocery shopping expedition and for which reasons they used it. The use of a mobile device during the last grocery shopping activity involved about $61.5 \%$ of respondents (see Table 2 ).

Table 2. Mobile usage during the last grocery shopping expedition

\begin{tabular}{lrrr}
\hline \multicolumn{4}{c}{$\%$ No mobile use \% Mobile useTotal } \\
\hline GenderMale & $12.8 \%$ & $25.3 \%$ & $38.1 \%$ \\
& Female $25.7 \%$ & $36.2 \%$ & $61.9 \%$ \\
Total & $38.5 \%$ & $61.5 \%$ & $100.0 \%$ \\
\hline
\end{tabular}

$35.7 \%$ of those who used mobile in-store, carried out activities related to grocery shopping, $8.9 \%$ personal activities not related to grocery shopping while about $55.4 \%$ respondents have made it a hybrid use (see Table 3 ).

Table 3. Reasons to use the mobile inside the store during the last grocery shopping expedition

\begin{tabular}{ll}
\hline Reasons for using the mobile inside the store & $\%$ \\
\hline Personal reasons not related to shopping (unrelated use) & $8.9 \%$ \\
Reasons related to shopping (related use) & $35.7 \%$ \\
Personal and shopping-related reasons (hybrid use) & $55.4 \%$ \\
Total & $100.0 \%$ \\
\hline
\end{tabular}

Out of the reasons cited for using the mobile in a shopping related manner, expressed in the questionnaire as predefined items, accessing and checking a digital shopping list prevailed as well as searching for product information, a sign of how the mobile is becoming increasingly a planning tool for pre-shopping preparation, especially for grocery shopping expedition, as confirmed by Bellini \& Aiolfi (2017). Moreover, interestingly, checking the promotions on the app accounted for $20.2 \%$ (see Table 4 ).

Table 4. Types of mobile usage in a shopping-related manner inside the store

\begin{tabular}{ll}
\hline Type of shopping-related mobile usage inside the store & $\%$ \\
\hline To check the digital shopping list & $58.3 \%$ \\
To look for product information & $39.3 \%$ \\
To male calculations & $38.1 \%$ \\
To check the promotions on the banner site / app & $20.2 \%$ \\
To pay & $20.2 \%$ \\
To use digital coupons & $14.9 \%$ \\
To scan the QR code & $13.7 \%$ \\
To call a family member / friend for information regarding grocery shopping & $12.5 \%$ \\
To compare product prices with other brands & $11.3 \%$ \\
To use the retailer's app & $8.9 \%$ \\
To surf the retailer's website & $4.8 \%$ \\
\hline
\end{tabular}


Furthermore, respondents were asked to indicate how often they use a mobile app to make purchases and how often to search for information on future purchases. The anchored measurement scale accounted 1 for an occasional usage and 7 for a very frequent usage. As shown in Table 6, 19\% of respondents clearly did not frequently use an app to make grocery purchases, while $19 \%$ say they frequently used an app to search for information for future purchases. Therefore, as shown in Table 5, the consumers interviewed are, in average, less accustomed to using a mobile app to make purchases (3.50 lower than the central value 4) while they are more accustomed to using it to search for useful information for shopping (4.48 higher than the central value 4).

Table 5. Frequency of use and reasons for using a mobile app for grocery shopping

\begin{tabular}{|c|c|c|c|c|c|c|c|}
\hline & 1 & 2 & 3 & 4 & 5 & 6 & 7 \\
\hline a) Use app to make purchases & $19.0 \%$ & $15.4 \%$ & $17.2 \%$ & $14.7 \%$ & $18.7 \%$ & $8.8 \%$ & $6.2 \%$ \\
\hline b) Use app to search for information on future purchases & $8.4 \%$ & $12.8 \%$ & $8.8 \%$ & $15.5 \%$ & $17.9 \%$ & $19.8 \%$ & $16.8 \%$ \\
\hline
\end{tabular}

Note. a) Mean=3.50; Std.Dev=1.833 b) Mean=4.48; Std.Dev=1.904.

In addition, shoppers answered to queries regarding their general tendency to prepare the shopping activities before entering the store and their general attitude towards the grocery app. Finally, we requested respondents to answer to queries about the perceived ease of use, perceived usefulness of the mobile app for grocery shopping and their intention to use the grocery app.

\subsection{Measures}

We measured all the variables considered in the model with multiple-item scales, with Likert measurement scale. Specifically, all the scales used in the survey come from previous research about shoppers and, once translated into Italian, have been adapted for our model to the context of grocery shopping and measured from 1 (disagree) to 7 (agree). The scale of the "perceived ease of use" and the scale of "perceived usefulness", already used in the TAM model, derive from a research by Fröhlke \& Petterson (2015). In addition, the "attitude towards the grocery app" scale derives from Fishbein \& Ajzen (1975) and the "intention to use the grocery app" from Al-rahmi \& Othman (2013). Finally, the "prepurchase planning" was designed by Gauri, Sudhir \& Talukdar (2008).

\section{Findings and Discussions}

To build the model we used a structural equation modelling approach with LISREL 8.8 and we tested the measurement model before analyzing the structural one, as recommended by Anderson \& Gerbin (1988) and Sethi \& King (1994).

For each variable or construct, the adequacy of the individual items and composites was assessed by measures of reliability and validity (Beatty\& Ferrell, 1998). First, we tested reliability using Cronbach's Alpha (Santos, 1999) and eliminated the items that would cause the worsening of the scale. Secondly, to test the convergent validity of our measures, we examined the significance of factor loadings (Anderson \& Gerbing, 1988) and the composite reliability. Furthermore, the discriminant validity was evaluated by comparing the extracted variance (AVE) with the square of the correlation between the two latent variables considered (Fornell \& Larcker, 1981). All the items considered for the SEM model are shown in Figure 3. 


\begin{tabular}{|c|c|c|c|c|}
\hline Items & $\begin{array}{c}\text { Factor } \\
\text { Loading }\end{array}$ & $\begin{array}{c}\begin{array}{c}\text { Cronbach } \\
\text { Alpha }\end{array} \\
\end{array}$ & $\begin{array}{l}\text { Composite } \\
\text { Reliability } \\
\end{array}$ & AVE \\
\hline $\begin{array}{l}\text { Perceived Usefulness of the app (Adapted from Fröhlke } \\
\text { and Petterson 2015) } \\
\text { 1. I believe that using a mobile device would make my } \\
\text { grocery shopping more effective } \\
\text { 2. I believe that using a mobile device would make } \\
\text { grocery shopping cheaper } \\
\text { 3. I think I would save time by using a mobile device to } \\
\text { do grocery shopping } \\
\text { 4. I believe that, in general, it is useful to use a mobile } \\
\text { device for grocery shopping }\end{array}$ & $\begin{array}{l}.859 \\
.808 \\
.823 \\
.927\end{array}$ & .914 & .916 & .730 \\
\hline $\begin{array}{l}\text { Perceived Ease of Use of the app (Adapted from Fröhlke } \\
\text { and Petterson 2015) } \\
\text { 1. It is easy to buy products through a mobile device / } \\
\text { smartphone } \\
\text { 2. It is easy to learn to buy through a mobile device/ } \\
\text { smartphone } \\
\text { 3. It is easy to use a mobile device / smartphone to do } \\
\text { grocery shopping } \\
\text { 4. I think it could be easy to use a mobile device / } \\
\text { smartphone during grocery shopping }\end{array}$ & $\begin{array}{l}.746 \\
.778 \\
.862 \\
.927\end{array}$ & .890 & .887 & .661 \\
\hline $\begin{array}{l}\text { Attitude towards mobile grocery app (Adapted from } \\
\text { Fishbein and Ajzen 1975) } \\
\text { 1. I think it's convenient to use my mobile device to do } \\
\text { grocery shopping } \\
\text { 2. I think it's a good idea to use the mobile device when } \\
\text { I shop for grocery } \\
\text { 3. I think it's good to be able to use my mobile device } \\
\text { when I shop for grocery }\end{array}$ & $\begin{array}{c}.933 \\
. \\
966 \\
.898\end{array}$ & .951 & .950 & .872 \\
\hline $\begin{array}{l}\text { Intention to use mobile grocery app (Adapted from } \mathrm{Al} \text { - } \\
\text { rahmi and Othman 2013) } \\
\text { 1. I plan to continue using a mobile app to buy products } \\
\text { in the future } \\
\text { 2. In the future I intend to increase the use of mobile } \\
\text { apps to make grocery shopping } \\
\text { 3. I'm going to recommend to my friends to use a } \\
\text { mobile app to do grocery shopping in the future }\end{array}$ & $\begin{array}{l}.770 \\
.953 \\
.906\end{array}$ & .905 & .911 & .774 \\
\hline $\begin{array}{l}\text { PrePurchase Planning - Propensity to plan } \\
\text { the expenditure (Adapted from Gauri, Sudhir and } \\
\text { Talukdar (2008) } \\
\text { 1. I prepare a shopping list before going grocery } \\
\text { 2. I arrange discount coupons before shopping } \\
\text { 3. I know the products I will buy before entering the } \\
\text { store } \\
\text { 4. I am a well-organized grocery shopper } \\
\text { B. Before going shopping, I plan my purchases based on } \\
\text { the offers / discounts of that week }\end{array}$ & $\begin{array}{l}.602 \\
.491 \\
.826\end{array}$ & .813 & 8.810 & .577 \\
\hline
\end{tabular}

Figure 3. Scale summary

\subsection{Measurement Model}

As far as reliability, we have found that all values are higher than the minimum acceptable value (0.70). Regarding the convergent validity, we have found all factors loading significant and the composite reliability of each construct is higher than the cut-off value (0.70). The data supports the discriminant validity for each construct since the extracted mean variance (AVE) exceeds the threshold value of 0.50 and in each factor exceeds the indicated correlation coefficient.

Finally, the measurement model has a good fit: $\chi 2=597.092$ ( $\mathrm{p}$-value $=0.0$ ), $\mathrm{df}=142, \chi 2 / \mathrm{df}=4.204, \mathrm{RMSEA}=0.083$, $\mathrm{CFI}=0.958$, std RMR $=0.0567$. All fit indexes are in line with the recommended ones (RMSEA $<0.09, \mathrm{CFI}>0.95$, $\operatorname{stdRMR}<0.06$ ).

\subsection{Structural Equation Model}

The overall fit of the structural model is good: $\chi 2=600.949$ ( $p$-value $=0.0$ ), $\mathrm{df}=144, \chi 2 / \mathrm{df}=4.17$, RMSEA=0.082, $\mathrm{CFI}=0.958$, std $\mathrm{RMR}=0.0588$ with all the fit indexes in line with the recommended values.

Figure 4 shows the final structural model with all the path coefficients (intensity and direction of relations) and the significance (t-value) for each of them. The results allow us to support all our hypotheses, except for $\mathrm{H} 7$.

Specifically, as expected, the results support all the hypotheses underlying the TAM model (H1: $\gamma=.738$, $\mathrm{p}$-value $<.000, \mathrm{H} 2: \gamma=.248$, p-value $<.000, \mathrm{H} 3: \beta=.715$, $\mathrm{p}$-value $<.000, \mathrm{H} 4: \beta=.322$, p-value $<.00, \mathrm{H} 5: \beta=.599$, 
p-value $<.000$ ). Interesting is the proof of the hypothesis H6 introduced for the first time in the proposed model and which highlights a direct and positive relationship $(\gamma=.088$, p-value $<.000)$ between the degree of grocery shopping preparation (PrePurchase Planning) and the positive attitude towards a mobile app for grocery shopping (Attitude towards grocery mobile app).

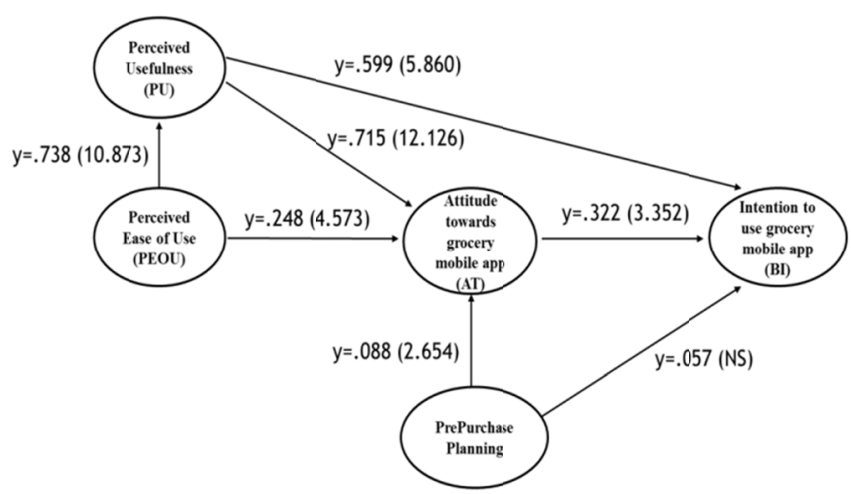

Figure 4. Structural model

By contrast, the relationship between the preparatory activity of shopping (PrePurchase Planning) and the intention to use the app for grocery shopping expeditions (Intention to use grocery mobile app) is not significant (H7: $\gamma=.057, \mathrm{p}$-value $>.01$ ). Therefore, it appears that there is no direct relationship between the degree of preparation of grocery shopping and the use of the app for grocery shopping but rather this relationship is mediated by the attitude towards the mobile app for grocery shopping.

\section{Conclusions and Managerial Implications}

The results of the proposed study confirm the validity of the application of the TAM model to measure the factors underlying the adoption of a mobile application for grocery shopping in Italy. The results support previous studies on the use of the TAM model and on its application for studies on mobile shopping (Shukla \& Sharma, 2018). The research enriches the literature on the adoption of mobile applications in the grocery setting where there are few researches that apply this model (Park, 2009; Shukla \& Sharma, 2018), in contrast to other context in which the TAM model has already reached considerable success. A further confirmation of the validity of the model comes from the fact that all the constructs proposed by the original TAM and their relationships were significant and relevant for our study, despite the specificity of the technology (mobile application) and the market (grocery setting). The contribution of this research relates to the validation of the TAM model in a new context such as the Italian one, in which studies on the adoption of innovative mobile technologies have not yet been conducted despite Italians being the most mobile addicted in Europe.

The model proposed should be considered as an extension of the TAM model for the specific context of grocery shopping because of the introduction of a new behavioral construct, the PrePurchase planning which impacts on the attitude towards the adoption of a mobile application for grocery shopping. The results are consistent with market and demand trends. In particular, recent changes in consumer behavior with an increase in preparatory activities have led them to adopt tools that can help them throughout the purchasing decision-making process. Moreover, the widespread mobile connectivity and the increasing penetration of mobile devices have strengthened these trends making consumers much more planned and prepared than ever before with shoppers who use the smartphone during the pre-purchase phase. Considering that individuals are becoming increasingly dependent on mobile technologies during their daily lives and that consumers increasingly rely on them, the understanding of the role of mobile devices in influencing the attitude of consumers towards the adoption of a 'mobile app in a grocery retail context is extremely important for retailers and manufacturers. A more planned and prepared consumer is more likely to adopt a mobile application during the buying process for activities related to grocery shopping. This should encourage retailers to develop mobile applications to exploit the dependence of consumers on technology in order to influence their behavior during the entire purchase process. This trend is even more relevant if you think that the mobile will be increasingly used during the shopping trip for purposes related to shopping task. Retailers, together with manufacturers should try to exploit this kind of mobile usage to influence shopper's perceptions and behaviors. The development of mobile applications that should be as easy as possible to use, useful and relevant to consumers will increase this opportunity. Today, consumers are ready to use mobile applications that facilitate their 
shopping expedition making them increasingly informed and prepared. Therefore, it is up to retailers to ride these trends and develop mobile solutions tailored to the needs of their consumers.

\section{Limitations and Future Research}

Despite the interesting theoretical and managerial contributions, the proposed model has some limitations. The structural model could be expanded by introducing some variables not included in the original TAM of Davis, Bagozzi and Warshaw (1989) but studied in the subsequent revisions of TAM2 and TAM3 as behavioral control and subjective norm.

Furthermore, we could revise the model and test an alternative model in which the PrePurchase Planning is considered an antecedent of Perceived Usefulness of the mobile grocery shopping app.

Another concern is about the generalizability. Our sample is probably neither truly random nor necessarily representative of any larger population. Our study, however, wants to be a first investigation about the adoption of mobile applications for activities related to grocery shopping. It is just a first step, which will open considerable opportunity for future research and for further experiment on innovative mobile applications in the grocery context.

In particular, further research might focus on the rise of augmented reality and artificial intelligence as tools to find new ways to capture the attention of the shoppers inside the store. These innovative technologies would increase the intention to use a mobile app in a grocery context.

Finally, for future research, we intend to enlarge the sample and investigate the phenomenon in different store formats to understand the impact of competitive convergence on shopping behaviour in-store.

\section{References}

Ajzen, I. (1991). The theory of planned behavior. Organizational Behavior and Human Decision Processes, 50(2), 179-211. https://doi.org/10.1016/0749-5978(91)90020-T

Al-rahmi, W., \& Othman, M. (2013). Using TAM model to measure the use of social media for collaborative learning. International Journal of Engineering Trends and Technology 5(2), 90-95.

Anderson, J. C., \& Gerbing, D. W. (1988). Structural equation modeling in practice: a review and recommended two-step approach. Psychological Bulletin, 103(3), 411.

Beatty, S. E., \& Ferrell, M. E. (1998). Impulse buying: modeling its precursors. Journal of Retailing, 74(2), 169-191. http://dx.doi.org/10.1016/s0022-4359(99)80092-x

Bellini, S., \& Aiolfi, S. (2017). The impact of mobile device use on shopper behaviour in store: an empirical research on grocery retailing. International Business Research, 10 (4), 58-68. http://dx.doi.org/10.5539/ibr.v10n4p58

Bellini, S., Cardinali, M. G., \& Grandi, B. (2016). Does shopping preparation influence consumer buying decisions? International Business Research, 9(10). https://doi.org/10.5539/ibr.v9n10p201

Bellini, S., Cardinali, M. G., \& Grandi, B. (2017). A structural equation model of impulse buying behaviour in grocery retailing. Journal of Retailing and Consumer Services, 36, 164-171. https://doi.org/10.1016/j.jretconser.2017.02.001

Block, L., \& Morwitz, V. (1999). Shopping list as a external memory aid for grocery shopping: influences on list writing and list fulfillment. Journal of Consumer Psychology, 8(4), 343-375. http://dx.doi.org/10.1207/s15327663jcp0804_01

Davis, F. D. (1989). Perceived usefulness, perceived ease of use, and user acceptance of information technology. MIS Quarterly, 319-340. https://doi.org/10.2307/249008

Davis, F. D., Bagozzi, R. P., \& Warshaw, P. R. (1989). User acceptance of computer technology: a comparison of two theoretical models. Management Science, 35(8), 982-1003. https://doi.org/10.1287/mnsc.35.8.982

Deloitte. (2017). Global Mobile Consumer Survey 2017.

Fishbein, M., \& Ajzen, I. (1975). Belief, attitude, intention and behavior: an introduction to theory and research.

Fong, N. M., Fang, Z., \& Luo, X. (2015). Geo-conquesting: competitive locational targeting of mobile promotions. Journal of Marketing Research, 52(5), 726-735. http://dx.doi.org/10.2139/ssrn.2439398

Fornell, C., \& Larcker, D. F. (1981). evaluating structural equation models with unobservable variables and measurement error. Journal of Marketing Research, 39-50. https://doi.org/10.1177/002224378101800104 
Fröhlke, M., \& Pettersson, L. (2015). What factors influence a consumer's intention to use a mobile device in the grocery shopping process? (degree project on global marketing). Lund University. Retrieved from http://lup.lub.lu.se/student-papers/record/7439512

Gao, L., \& Bai, X. (2014). A unified perspective on the factors influencing consumer acceptance of internet of things technology. Asia Pacific Journal of Marketing and Logistics, 26(2), 211-231. https://doi.org/10.1108/APJML-06-2013-0061

Gauri, D. K., Sudhir, K., \& Talukdar, D. (2008). The temporal and spatial dimensions of price search: insights from matching household survey and purchase data. Journal of Marketing Research, 45(2), 226-240. https://doi.org/10.1509/jmkr.45.2.226

Hackbarth, G., Grover, V. \& Mun, Y. Y. (2003). Computer playfulness and anxiety: positive and negative mediators of the system experience effect on perceived ease of use. Information \& Management, 40(3), 221-232. https://doi.org/10.1016/S0378-7206(02)00006-X

Heckhausen, H., \& Gollwitzer, P. (1987). Thought contents and cognitive functioning in motivational versus volitional states of mind. Motivation and Emotion, 11(2), 101-120. http://dx.doi.org/10.1007/bf00992338

Hu, P. J., Chau, P. Y., Sheng, O. R. L., \& Tam, K. Y. (1999). Examining the technology acceptance model using physician acceptance of telemedicine technology. Journal of Management Information Systems, 16(2), 91-112. https://doi.org/10.1080/07421222.1999.11518247

Iyer, E., \& Ahlawat, S. (1987). Deviation from a shopping plan: when and why do consumers not buy items as planned. Advances in Consumer Research, http://acrwebsite.org/volumes/6696/volumes/v14/NA-14

Karahanna, E., \& Straub, D. W. (1999). The psychological origins of perceived usefulness and ease-of-use. Information \& Management, 35(4), 237-250. https://doi.org/10.1016/S0378-7206(98)00096-2

Kim, M. J., Chung, N., Lee, C. K., \& Preis, M. W. (2016). Dual-route of persuasive communications in mobile tourism shopping. Telematics and Informatics, 33(2), 293-308. https://doi.org/10.1016/j.tele.2015.08.009

Ko, E., Kim, E. Y. \& Lee, E. K. (2009). Modeling consumer adoption of mobile shopping for fashion products in Korea. Psychology \& Marketing, 26(7), 669-687. https://doi.org/10.1002/mar.20294

McKechnie, S., Winklhofer, H., \& Ennew, C. (2006). Applying the technology acceptance model to the online retailing of financial services. International Journal of Retail \& Distribution Management, 34(4/5), 388-410. https://doi.org/10.1108/09590550610660297

Moon, E., \& Domina, T. (2015). Willingness to use fashion mobile applications to purchase fashion products: a comparison between the United States and South Korea. Journal of Textile and Apparel, Technology and Management, 9(3).

Park, S. Y. (2009). An analysis of the technology acceptance model in understanding university students' behavioral intention to use e-learning. Journal of Educational Technology \& Society, 12 (3), 150.

Roberts, P., \& Henderson, R. (2000). Information technology acceptance in a sample of government employees: a test of the technology acceptance model. Interacting with Computers, 12(5), 427-443. https://doi.org/10.1016/S0953-5438(98)00068-X

Santos, J. R. A. (1999). Cronbach's Alpha: a tool for assessing the reliability of scales. Journal of extension, $37(2), 1-5$

Sethi, V., \& King, W. R. (1994). Development of measures to assess the extent to which an information technology application provides competitive advantage. Management science, 40(12), 1601-1627. https://doi.org/10.1287/mnsc.40.12.1601

Shukla, A., \& Sharma, S. K. (2018). Evaluating consumers' adoption of mobile technology for grocery shopping: an application of technology acceptance model. Vision, 22(2), 185-198. https://doi.org/10.1177/0972262918766136

Silveira, P., \& Marreiros, C. (2014). Shopper marketing: a literature review. International Review of Management and Marketing, 4(1), 90-97. Retrieved from http://dergipark.org.tr/irmm/issue/32079/355047

Taylor, S., \& Todd, P. (1995). Assessing it usage: the role of prior experience. MIS quarterly, 561-570. https://doi.org/10.2307/249633

Thomas, A., \& Garland, R. (2004). Grocery shopping: list and non-list usage. Marketing Intelligence \& Planning, 
22(6), 623-635. http://dx.doi.org/10.1108/02634500410559015

Venkatesh, V., \& Bala, H. (2008). Technology acceptance model 3 and a research agenda on interventions. Decision sciences, 39(2), 273-315. https://doi.org/10.1111/j.1540-5915.2008.00192.x

Venkatesh, V., \& Davis, F. D. (1996). A model of the antecedents of perceived ease of use: development and test. Decision sciences, 27(3), 451-481. https://doi.org/10.1111/j.1540-5915.1996.tb00860.x

Venkatesh, V., \& Davis, F. D. (2000). A theoretical extension of the technology acceptance model: four $\begin{array}{lllll}\text { longitudinal field studies. } & \text { Management science, } & \text { 46(2), } & \text { 186-204. }\end{array}$ https://doi.org/10.1287/mnsc.46.2.186.11926

Venkatesh, V., Morris, M. G., Davis, G. B., \& Davis, F. D. (2003). User acceptance of information technology: toward a unified view. MIS quarterly 425-478. https://doi.org/10.2307/30036540

Venkatesh, V., Thong, J. Y., \& Xu, X. (2012). Consumer acceptance and use of information technology: extending the unified theory of acceptance and use of technology. MIS quarterly 157-178. Retrieved from https://ssrn.com/abstract $=2002388$

Wu, J. H., \& Wang, S. C. (2005). What drives mobile commerce? an empirical evaluation of the revised technology acceptance model. Information \& Management, 42(5) 719-729. https://doi.org/10.1016/j.im.2004.07.001

\section{Copyrights}

Copyright for this article is retained by the author(s), with first publication rights granted to the journal.

This is an open-access article distributed under the terms and conditions of the Creative Commons Attribution license (http://creativecommons.org/licenses/by/4.0/). 